\title{
Racism and Schools in Mexico: Seeking a Solution by Recognizing the Tragedy
}

DOI: https://doi.org/10.32870/dse.v0i13.242

\section{Saúl Velasco Cruz* \\ Bruno Baronnet**}

Translation by Joshua Sol Lewis

joshua.sol.lewis@gmail.com

\begin{abstract}
"Gallo, caballo y mujer, por su raza has de escoger" ("Choose your rooster, your horse, and your woman according to their breed")

(Anonymous Mexican saying) "No tiene la culpa el indio, sino el que lo hace compadre" ("Don't blame the Indian, blame the one who befriended him")
\end{abstract}

(Anonymous Mexican saying)

\begin{abstract}
Racism in Mexican society is reproduced through curricular content and everyday practices in schools. Its elimination is a social imperative demanded by historically discriminated groups. Nonetheless, this demand has not translated into significant educational policy because racism is very convenient for power relations that maintain the current social order. In this context we propose in this essay to identify and define possible avenues towards helping educational actors, primarily teachers, engage in concrete antiracist activity. Key words: racism, education and racism, K-12 education, Indigenous education, teacher training, antiracism.
\end{abstract}

\section{Introduction}

Sayings hold a central place in Mexican society. They transmit advice, modes of thinking, forms of being and ways of understanding the world. This very idea can be summed up and understood in a saying: "los dichos de los viejos son evangelios chiquitos" ("the sayings of the old timers are miniature gospels"). Gospels are not debated, they are merely accepted. Sayings are a reflection of a widely shared worldview. Apparently they are timeless - nobody knows exactly when they came about, and in any case that isn't important. What is important is, firstly, the message of the saying, secondly, the eloquence with which it passes judgment, and lastly, its capacity as self-fulfilling

*Sociologist. Full time research professor at National University of Pedagogy, Ajusco branch, Mexico City. SNI level ${ }_{1}$. Member of group: Education, Interculturality, and Racism, part of the Network of Interdisciplinary Investigation of Identities, Racism, and Xenophobia, (INTEGRA Network), funded by Conacyt. E-Mail: velascosaul@gmail.com

**Sociologist. Full time research professor at Institute of Education Research, University of Veracruz, SNI level 2. Coordinator of group "Education, Interculturality, and Racism" part of the INTEGRA Network. IIE-UV, Campus Sur, Xalapa, Veracruz. E-Mail: bruno.baronnet@gmail.com 
prophesy. Racism in Mexican society is of this caliber. A racism that's like an entire book of sayings. This is where this article begins. We don't intend to discuss the origins of racism but rather to describe it in order to give it a face and name, nothing more. We want to make clear that there is something more at play here than a single racism.

Racisms have deep roots in schools, thus it seems important to describe the scholastic context from which they emerge in order to explore a path to their elimination. This sociology of education essay is divided into six sections that lead to a concluding proposal for the eradication of racism in Mexico starting at the school level. After detailing the structural nature of the institutionalization of racism in society, we describe its repercussions in the field of curricular processes, manifesting not only as a historical legacy but also as the product of the hierarchization of scholastic skills and content that seek to measure, classify, and alter the "intelligence" of children. After examining what is at stake in the specific context of Indigenous education in Mexico, we ask whether it is possible to dismantle racism and what the principle emergent challenges would be for a school with an antiracist curriculum.

\section{Structural and institutional racism}

We live in a racist society. The award-winning Kenyan-Mexican actress Lupita Nyong'o made this clear when, after gaining fame through her exceptional acting, she revealed the crudeness of Mexican racism to the world in December, 2015. ${ }^{1}$ Around the same time, Ali Roxox, a K'iche' woman from Guatemala, doctoral candidate at a research center in Chiapas, revealed to the international community the realities of racism on the southeastern border of Mexico. She described how she had been "kicked out of a café in San Cristóbal de Las Casas, Chiapas, after being profiled as a street vendor" because of her Indigenous appearance. ${ }^{2}$ Those that denied the woman entrance to the café were employees, local youth possibly with the same ethnic background (Mayan) as Ali, but who, due to their occupational context, were acting as mere conduits of a racism that had been deeply ingrained into their subjectivities, a racism which compelled them to uphold conventional, normal, or normalized order through superficially autonomous decision-making mechanisms.

1 Lupita Nyong'o won an Oscar for her performance in the movie "12 Years a Slave." She revealed to the French fashion magazine Elle that her childhood in Mexico was fraught with racism. She described how, during the time she lived with her family in Taxco, Guerrero, "the attention on the street was traumatizing. We were like an exotic attraction. People would stop us to take pictures just because we were black. It was a difficult moment, during adolescence, just when you're discovering yourself and trying to find your path but you are in an insecure place. It devastated me." Cited in the e-newsparper Sin embargo, available at: http://www.sinembargo. $\mathrm{mx} / 03-12-2015 / 1569528$

2 A friend that was with her at the time described the event thus: "Such a beautiful day and they've just kicked us out of the French café-bakery $O h L a L a$. They stopped Ali Roxox at the door in an abusive manner, telling her that she couldn't come in to sell. It's not the first time that this has happened to us. I'm fed up with so much racist humiliation and violence towards Indigenous women in this town". Cited in Proceso: I. Mandujano (2013). "Echan de una cafetería a indígena estudiante de doctorado tras confundirla con una vendedora ambulante". April 13th, 2013, available at: http://www.proceso.com.mx/357788/echan-de-una-cafeteria-a-indigenaestudiante-de-doctorado-tras-confundirla-con-una-vendedora-ambulante (Última visita, 11 de abril de 2016). 
Similar cases, of varying degrees of severity, abound daily in Mexico; that is to say, they are not mere exceptions to the rule. Mexico, apart of having an unjust and unequal society, it has a racist society, as it has been revealed with concrete data in surveys on discrimination conducted by the National Council of Discrimination Prevention (CONAPRED), as well as by scientific studies carried out by Castellanos Guerrero (2003 and 2012), Gall (2004 and 2007), Gómez Izquierdo (2008), Moreno Figueroa (2010), París Pombo (2002), Saldívar (2012), Navarrete (2016), Iturriaga (2011), Menéndez Spina (2001 and 2016), and Urías Horcasitas (2007). The question is, why is Mexican society racist? We posit that the causes can be traced to Mexico's extensive institutional history. Using a wide historic lens it's possible to discern the long-term influence of certain historical events, starting with, as Aníbal Quijano has impeccably explicated, the Spanish conquest, followed by he Colonial Era, leading to era of Independence in which the dominant influence of Western thought would mold different models of Mexican society throughout the $19^{\text {th }}$ century and become the fundamental base for confirming and crowning the society that emerged from the Mexican revolution as racist.

In this sense the racism oriented by the idea of "México mestizo," which José Vasconcelos defended so eloquently in his book, The Cosmic Race (1925), was not in any way personal or spontaneous, but rather represented the accumulation and channeling of a constellation of informal xenophobic tendencies that seem to have converged around the idea of explicitly building a society completely idiosyncratic in its conception and production of race and racism. In terms of the racism that permeated the state's project, the path would be, at least at the discourse level, to put the Mestizo on a pedestal as an ideological and political prototype and ideal, as long as the established order maintained Western thought as its guiding light. In this framework the Mestizo would become - particularly at the beginning of the 1930's - the political resource par excellence to achieve the "new society" which, as in other contexts in the Western world, was driven by a eugenist, selective logic.

The racist project for the white elite, on the other hand, didn't change course at all. The safeguarding of origins and the maintenance of whiteness - i.e. white European skin color and phenotype - continued to be of the utmost importance, as it has throughout history. A similar dynamic occurred with other elites who coveted white privilege, with the only difference being, to take an idea from F. Navarrete (2016), that their ambition was fundamentally aspirational, that is to say, they wanted to "whiten" their heritage as quickly as possible. Thus the idea of México mestizo invented by the Mexican revolution created a more presentable Mestizo-centric façade for the crude and harsh racism that has characterized every stage of Mexican society, all the while continuing to unconditionally concede privileges to whites to the detriment of non-whites, albeit with degrees of intermediate class privilege granted to aspiring Mestizo groups. 
Ideal vs. real racism in society and education

The realities of racism in society are replicated in schools. Considering that Mexican society is riven with racism, we must be constantly mindful of how the fact of ideal racism - which held and continues to hold "mestizaje" ("racial mixing") as an ideal - articulates with the complexities of real racism. In practice, diverse racisms (such as those pointed out above) mingle under the umbrella of the racism of mestizofilia (Basave, 1992). Despite the complexity of this problematic, it is important to remember that ideological and mental processes that are based on the belief that there should be a racial hierarchy of human cultures feed off racisms.

As phenomena that are ideological in nature, racisms don't arise spontaneously but rather need be taught and learned, as T. Van Dijk (2007) has pointed out, and in this education plays an important role. Wherever education takes place, in all of the spaces and instances where it occurs, racist ideas can be taught and learned; that is to say, such ideas circulate through classrooms, schoolyards, didactic material, chalkboards and smartboards. These ideas are also present in the auditoriums, hallways, and offices of public institutions of higher education, including those that train teachers, making it essential to investigate and intervene in specific university and regional contexts such as the University of Guadalajara and the state of Jalisco (Carlos Fregoso, 2016; Cejas, 2004).

In practice there isn't one exclusive form of learning cultural and class prejudices, although to date schools have proven to be prone spaces in this sense. As several specialized studies have documented (Masferrer, 2012; Saldívar Tanaca, 2012; Velasco Cruz, 2016), the racism of mestizofilia, which materializes an ideal racism, continues to be taught in primary schools in Mexico, including those in the Indigenous education subsystem. Despite fairly periodic curricular adjustments and reforms, free and commercial textbooks continue to reproduce lessons replete with explicitly or implicitly racist characters that have been amply identified. In the same fashion, racist ideas translate into discriminatory practices that pervade K-12 schools.

This situation is all too common in student interactions and tends to be as well in interactions between teachers and students and in everyday relations in the so-called scholastic community. At the apex of official rhetoric of "intercultural" and "community" education - which claims to seek recognition and valorization of all native cultures in the country - as well as the proliferation of institutions which, based on the law against discrimination, should by constitutional mandate safeguard the prevention and eradication of discrimination, racism has not declined. On the contrary, as has been observed in works by J. R. Gnade (2008), D. Hernández Rosete (in press), and B. Baronnet (2013), racism and discrimination in schools are rooted in the exacerbation of racist tendencies that permeate Mexican society.

\section{Comfortable and uncomfortable racism in schools}

K-12 education, oriented around the Mestizo referent, seeks to create an atmosphere amenable to the same. In this sense Mestizos, or those that assume or can pass with that identity, can feel a 
certain level of comfort in school. But not so for those who don't have that identity. The Mestizo conformity that the school intends to produce can create a certain xenophobia towards White elites, but above all it tends to provoke aggravating and uncomfortable situations for Afro-Mexicans, Indigenous-Mexicans, and other minority groups. If the Mestizo mix is the rule, everything outside is relegated to the shadows of abnormality. To be White in a Mestizo environment is a basis for standing out and being deemed abnormal. It is motive for scorn not only in relation to one's cultural background, but also in relation to one's social background in lieu of the class racism that operates in contemporary societies (Balibar and Wallerstein, 1990). Given that the racism of mestizofilia is not the only racism in operation, although it does constitute the prevailing official position that is highlighted in scholastic content, White identity can become - for reasons that lie outside of schooling - a distinction (the opposite of rejection), an indubitable advantage, very unlikely to result in the rejection that invariably occurs with other identities such as Afro-Mexican or IndigenousMexican.

Usually we understand schooling as a systematic and organized affair, with lesson plans and content organized gradationally and rationed out according to a long-term plan which a student has to undergo in its entirety in order for it to have a transformative effect on his or her life. Thus schooling is defined as an activity that necessitates discipline and consistency in order to advance past each stage, although this is not always adhered to. It is precisely from this routinized, normalized, almost fordist discipline that racism benefits, thriving on the scholastic program of reiterative, mandated, and systematically rationed out content and practices, as Gnade (2008) observed in his research on the content of elementary school textbooks in the Indigenous sub-system.

School practices, curricular content and syllabi rigorously shape and model personalities, subjectivities, and ways of thinking, acting, and feeling. Schools are key spaces of political socialization which involve the acquisition of modes of understanding and interacting with the world, the idea of social order and the social order itself. All of this is realized with extreme diligence, under the precepts of producing a disciplined subject who is tenacious, constant, and not intimidated or discouraged by the fact that from this same discipline and constancy there should arise, paradoxically, a critical, innovative, creative, and even humanist spirit in those that have gone through the schooling process.

Although it seems contradictory, all of this is understood and accepted as indispensable and appropriate. Teaching the social order, normalizing it, as it were, can be done in ostensible harmony with the endeavor of cultivating and stimulating curiosity, knowledge, and the intellect. Bourdieu (1990) found in this contradictory double movement what he calls "the racism of intelligence" through which those in power come to feel as if of a superior essence, thereby justifying their domination of the social order. Thus it is imperative to analyze how elites dominate a society on the basis of forms of discrimination centered around "intelligence," or as Bourdieu points out, based on what the scholastic system measures under the name of intelligence. The social hierarchy generated 
by the use of standardized testing is not so different than that which is based on social background, since the oppressed continue to be predominantly poor and non-white (Croizet, 2103). This selective process seems to be well accepted in the Western world because it allows the legitimization of arbitrary classifications, thus breathing new life into a social Darwinist, eugenics-based racism that determines which are considered the most apt and gifted intellects. In the case of Mexico, the tensions generated by racial inequalities in education and the effects of racism in curricular processes (McCarthy, 1993) are manifested in the political controversies surrounding standardized testing in Spanish in Indigenous schools in Chiapas. These schools constitute true racism-of-intelligence factories.

All of this explicit activity in schools spawns its opposites. Whatever doesn't fit into the established order is its antithesis: disorder. Whatever doesn't fit under the umbrella of normalcy is out of place and can be disqualified, combated, and, if possible, forced into submission and eliminated. Thus, forms of order and living that are different than what schools posit as legitimate are, in the best of cases, mistrusted. A similar dynamic occurs with alternative worldviews. Cultures, languages, and systems of knowledge that don't fit into scholastic boundaries are pushed by principle and by norm into the shadows of ineligibility. Until they are purified with a "monocultural cleansing" that can make them complementary or compatible with school or what has been socially validated as normal, they will have no other place but on the outside, the side of what is excluded and rejected. This is run-of-the-mill. This is what anyone studying schools should learn and accept as true. This is the basis of the legitimization of racism in school practices and content.

What has been discussed up to now has received scarce attention in the academic world. In general, there have been some specialized studies that approach the topic of education - Gómez Izquierdo (2005), Molina Ludy (2000), Saldívar Tanaca (2012), Gnade (2008), Masfarrer (2012), Hernández Rosete (in press) - but the majority of them are recent and have had a marginal impact on college teaching. Nonetheless, this gap in scientific attention can be complemented with contributions from the fields of sociology, political science, and anthropology, which have taken up the task of studying the discriminatory characteristics of Mexican society and education. By taking such an interdisciplinary approach it's possible to arrive at the conclusion that racism in schooling derives (from a wide-lens perspective, of course) from the order imposed by the Conquest and Colonialism, from the order that followed in what is known as Independence Era in Mexico, but more than anything, from the project of "Mexico Mestizo" which, inheriting all of the previous paradigms, inspired the institutionalized model of society that resulted from the post-revolutionary period after 1910. During this period public education had the task of modeling this new society. In this sense racism in Mexican K-12 education cannot be considered as an anomaly, failure, mistake in the system, or intrinsic, internal shortcoming disconnected from the overarching order that it is couched in. Quite the contrary. 
Racism in K-12 education is a basic ingredient, deliberately added in order to achieve a very specific product: the manufacture of Mexican citizens and professionals. It seeks to shape a society that is proud of its Indigenous past and Spanish heritage, but with both sides merging around the controversial and unattainable figure known as "Mestizo." This effort has been labeled as Mestizofilia by A. Basave (1992) - a feeling of preference for this particular mix.

Although some might think that that a project of national unity of this type has been left in the past or lost strength, it does in fact endure and is visible today in the contents of K-12 and higher education. Gnade provides a meticulous study that shows how strongly racist elements persist in current educational curricula and textbooks at all scholastic levels. Hernández Rosete (in press) in Baja California, and Baronnet (2013) in Chiapas argue that racist stereotypes are manifested in everyday teaching practice, in the interactions observed in school spaces, and in the relationships between teachers and families.

Fathers, mothers, and community authorities are frequently called on to organize fund-raising events and make material "donations." Nonetheless, they are denied any opportunity to intervene in teaching practices, content, and/or evaluations. Racism legitimizes the assumption that towns and neighborhoods are incapable of participating in the design and implementation of an education that might be contextually flexible. In neoliberal social projects it has become more and more acceptable to deny working class families any shred of legitimacy in deciding and evaluating what type of education their children receive in schools.

This racist social project consigned to schools has been denounced in different periods by distinguished intellectual critics, including Mexican anthropologists, sociologists, political scientists, and philosophers, as well as by foreigners with an interest in the case of Mexico. There are numerous historic cases wherein those affected by this project (principally Indigenous peoples), have united behind leaders and social movements to denounce the hegemonic racist social project entrusted to public schools (Mejía y Sarmiento, 1987). Many have contributed to the understanding that racism in schools is a continuation of the racist model of society that continues to be defended across the board inside and outside of schools. This dynamic also comes to bear upon what is known as Indigenous education, which was created by the post-revolutionary regime in the 1930's with the aim of implementing a special, integrative educational program adapted to the linguistic and ethnic characteristics of the native peoples of Mexico.

\section{Racism in indigenous education}

Without specifically intending to write about racism in the Indigenous education subsystem, E. Ramírez, in his book Educación indígena en México (2006), emphatically reveals the manner in which the educational program for Indigenous groups created by the post-revolutionary regime left unchanged the racism that had been inherited with almost every single project, big and small, since Colonial times. Of course from one time period to another strategies changed, but the essence 
remained and still remains the same. In its content and practices racism in Indigenous education is active; at least that is the conclusion that can be drawn from recent studies in the field by authors such as Gnade, Baronnet, Saldívar Tanaca, and Hernández Rosete. The Indigenous educational subsystem, as with every other official educational program, immerses children, teenagers, and native cultures, knowledges and worldviews in racist perspectives. Every single aspect of the pedagogical program is imbued with racism. There's no way of ignoring it, no matter how generous a gaze is cast. The use of native language - one of the subsystem's principal characteristics - when it does occur, is completely subtractivist (Hamel, 2004; Muñoz Cruz, 1987; Rebolledo, 2010); that is to say, native tongues are used merely as resources to facilitate the learning of Spanish, since the latter is what is required in subsequent levels of education. The educational program that guides the use of the mother tongue is the same as that of general education, and the same is true of the textbooks. The teachers who in theory should be fluent in the language of their students sometimes are properly placed in communities that do speak their linguistic variant, but other times they are placed in communities that speak a different language. Not all have gone through standard teacher training programs (Velasco Cruz, 2015); usually many of them get certification through a short two-month course (Jordá Hernández, 2000). Even as the censuses of recent decades show that Indigenous families are located in large towns, developed agricultural centers, and cities, Indigenous education continues to be offered primarily in rural places. Further, teachers in the Indigenous education subsystem, as has been observed in the fieldwork of Hernández Rosete (in press), promote racism in their interactions with students.

In the 1970's, some teachers in the Indigenous education subsystem, organized in groups such as the National Alliance of Bilingual Indigenous Professionals (ANPIBAC), denounced failures observed in the system (Mejía and Sarmiento, 1987). Some of the criticisms were clearly related to racism. Stefano Varese and other scholars of topics related to Indigenous education participated in a project named "Culturas Populares", which made similar criticisms (Pérez Ruiz and Argueta, 2015). Noted intellectuals in the 1980's and 90's also spoke out on the topic. As a result, Indigenous education began to go through some formal changes: it was labeled as Bilingual, then Bilingual Bicultural, and ultimately, Intercultural Bilingual. Nonetheless, the racism that accompanied the program was never eliminated. In his dissertation research, Gnade (2008) found racism very much alive in the content of Indigenous education textbooks, years into this so-called era of intercultural education. Those findings coincide with research of racist discrimination in education for the AfroLatino populations in countries such as Brazil (Gallo, 2015) and Colombia (Mena, 2011), in which evidence is presented of the state's role in violating human dignity.

\section{Is it possible to dismantle racism?}

In the 1990's several academic studies came out that pointed to the benefits of adopting intercultural approaches to counteract and dismantle racism in education. These arguments furthered the 
debate that would help Indigenous education become, at least nominally, as has been discussed, an intercultural alternative. Similar arguments would later reach the mainstream primary education world, which at the beginning of the $21^{\text {st }}$ century also began to define itself as intercultural. Some backers of this turn, including S. Schmelkes, were quick to give it the label of "interculturalism for all." Books, essays, articles, conferences, congresses and lectures produced possibilities for change. And there were indeed changes. At the federal level institutions were created (CGEIB, INALI) which were staffed with working groups who edited multilingual manuals, research, and a variety of intercultural workbooks that came off official presses.

In an era where interculturalism is institutionalized in official discourse but almost invisible in pedagogical practice, even racism is subject to innovation; from being primarily rooted in a notion of primordial racial groups, it suddenly turned to culture as its racialized variant. It is to intercultural education that we owe the re-launching of racism, but now as cultural racism. Cultural racism is more recent, corresponding to the decades preceding the end of the Cold War and appearing in full force after its culmination. Wieviorka (2009), in his book, Racismo, una introducción, explains this change as a decline in racism based on the concept of biological races. Nonetheless, it seems that racism of race wasn't substituted; it exists, unperturbed, alongside cultural racism.

Faced with such conclusions, some have come to believe that interculturalism in education has worn out its promise and is on its way out, given that it isn't achieving the positive effects that its proponents championed (Díaz-Couder and Gigante, 2015). On the other hand, there are some who consider that the interculturalist approach still has the potential to counteract and dismantle racism in education, insofar as it can break with the inherent limits of its official articulation. In this vein alternative approaches have been tried out within the official educational system. Teachers in Oaxaca have taken initiatives to give themselves increased agency, and, with a highly symbolic play of words, have proceeded to "take over" schools (this is the name they have given to their project of self-management), with the aim of converting them in institutions at the service of communities. These initiatives seem directed at counteracting the hegemonic and racist influence of the national educational program.

In the state of Michoacán some schools are doing something similar through agreements between teachers, parents, and community assemblies (Medina, 2012; Hamel, 2004). There have been cases of other types of initiatives as well. They don't deny the possibilities of a community-based, intercultural approach, but they do take a significant distance from the national educational system. This is the case with autonomous educational alternatives which are being practiced in the schools of Zapatista communities in Chiapas (Baronnet, 2013). Although they are heterogeneous in nature, all of the cases mentioned seem to create antiracist possibilities in education.

Much is said of schools: how they serve to reproduce social structures of domination and inequality, as pointed out by Bourdieu and J. - C. Passeron; how they contribute to the subordination of local knowledges; or how as institutions of power it would be best to imagine a "deschooled so- 
ciety," as I. Illich proposed four decades ago and G. Esteva maintains today, arguing that "to resist school and abandon education implies substantively broadening the dignity of ordinary men and women and defying every existing political and economic system" (Esteva, 2011: 172).

Other thinkers have found that schools are sites in which Colonial thought is taught and recreated, diversity is negated, and alternative epistemologies that fall outside of Western schema are effectively murdered. Alongside new tendencies that are favorable to the analysis of schools as instruments of Colonial domination but also see them as spaces of resistance and community building (Maldonado, 2000), there are teacher collectives that still follow the critical perspectives passed down by J. Dewey, which see schools as sites of possible democratization, F. Ferrer Guardia, who saw libertarian potential in his proposal of "modern schools," and C. Freinet, who proposed contemporary techniques that inspire cooperative pedagogies.

Furthermore, many contemporary sociologies of education have furthered the idea that a school can produce educational experiences determined by social demand (Dubet and Martuccelli, 1998). A complementary approach is found in the ideas of Paolo Freire, which hold that by turning education into an act of "conscientization" (consciousness raising) it can become an emancipatory act on various levels. It has also been argued that schools have antiracist potential. It is a possibility. Some alternative experiences within the Mexican education system, as well as some outside it, are testifying to this.

\section{Antiracist challenges for schools}

In Mexico not all schools have the same antiracist imperatives because not all experience racism in the same way. The racist content and practices of México mestizo in schools where the majority of the population is Mestizo is a racism that is comfortable for teachers and students. On the other hand, mestizophile racism has devastating effects on Indigenous and Afro-Mexican boys and girls, teachers, and communities. It's true that in both cases racism is practiced. Content is invariably laced with explicitly or implicitly racist statements and in both contexts teachers bear responsibility for whether or not those racist elements are experienced and performed in a given school. This is due to the fact that in K-12 education the majority of decisions are made by teachers. They control whether racist content is taught or not. There is a similar dynamic with racist practices, although it can be said that not all interactions are subject to teacher control. In any case, what is certain is that it is in schools pertaining to the Indigenous subsystem that the most crass and brutal racism appears.

The unprecedented nation-wide inquiry by the National Institute for Education Evaluation (INEE) in 2015 publicized Indigenous communities' opinions concerning the education that they receive. In response to certain survey questions Indigenous people stated that schools discriminate against them and exclude their knowledges, forms of organization, and world-views. This attitude was widely shared throughout different communities. The widest complaint concerned teachers 
not having sufficient sensibility for their job. Teachers were seen as mere executioners of official decrees that furthered the alienation of Indigenous children. Teachers were given access to the gathered opinions. In response, teachers recognized that they haven't always been able to ameliorate the discriminatory and exclusionary effects of their actions on the communities they work in. Nonetheless, many suggested that it is the communities that frequently exclude and marginalize themselves.

In mainstream schools, as with Indigenous schools, the possibility of acting against racism depends largely on teacher training programs. If teacher trainers can make trainees conscientious and able to recognize that their intervention can and will change reality, then everything can change. But experience has shown that this is not such an easy task. As it was verified by J. Aguilar Nery (2012) in research on this topic, teachers have learned throughout their lives and schooling that racial differences exist, that they are a fact, and classifying human beings in this manner is legitimate. Racism is thus normalized and resides in the subconscious as a natural classifying tendency that responds to the mandates of an internal government, that is to say, to the biopolitical imperatives that subconsciously regulate many of their actions. Thus one of the principle challenges in antiracist work consists in raising consciousness regarding the significance of racism and its implications. This would necessarily entail learning what racism is, how it is manifested, and what effects it provokes, thus making clear the necessity of eliminating at the root any normalization it enjoys in the subjectivities of teachers and in their teaching practices. Here self-surveillance by teachers regarding teaching practices and scholastic content is key.

\section{Final considerations}

Probable levels of antiracist scholastic activism

Local activism

Based on what has been said, it is clear that for antiracism work in education the cases are as many as there are schools and local or regional projects based around the issue. There are some examples that deserve to be mentioned.

In the context of the war in Guatemala in the 1980's and 90's, Comunidades de Población en Resistencia (Communities of People in Resistance) fomented a multicultural education carried out in precarious conditions by Indigenous "facilitators" trained in cooperatives and peasant farmer (campesino) movements. During armed conflict and "resistance," everyday practices are steeped in alternative political education galvanized by social movements, acquiring in this context autonomy and independence from public institutions. Here the young facilitator takes on the pedagogical task as an act of militance, "but this will is undermined by a government power that continues to be racist towards Indigenous people, since he or she is accustomed to oppressive, colonial processes"; nonetheless, training during the resistance "fortified the presence of teachers who are autonomously visualizing an intercultural social movement" (Muñoz Sánchez, 2015:122). To a 
certain extent it seems that mobilizations of this type constitute a condition for the strengthening of capacities of action and reflection by community actors involved in preventing education from reproducing hierarchies generated by the racialization of inequalities.

In the struggle for antiracist education it is also fundamental to cultivate local conditions conducive to Indigenous and Afro-Mexican oversight of pedagogical materials, supported by collaboration with Whites and Mestizos, thereby "forming an army of citizens and political activists that subverts the verticality of the monocultural state so that the latter's actors and institutions modify their ethnocentrism and learn - as is taught by the Zapatista movement in Mexico - 'to lead by following"" (Bertely, 2011: 42). Contributions by local educational research can help determine in minute detail what interactional conditions favor or impede the situated emergence of antiracist education. It is on the basis of innovative initiatives for critical teacher training, combined with courses and workshops directed to capacitating adults (not just teachers), that an efficacious fight against racist discrimination in education can take place. General education on the histories and collective rights of Indigenous people can be a powerful tool for breaking up the culture of disparagement predominant in our society (Baronnet, 2013) which impedes native peoples from enjoying rights of access and continuity in schools and creating educational centers that might defend local territories threatened by global forces.

\section{Global action}

Local antiracist activism should be complemented by broader work aimed at curricula from whence textbooks and their content derive. Apart from vigilance over teaching practices, which we've already discussed, there would have to be a similar intervention in scholastic content. Preventive action is required that would eliminate implicit and explicit racism contained in scholastic curricula. If something similar was successfully done in terms of secularizing education by removing religious references from textbooks and classrooms, something similar can be done here. If, as J. Habermas (1999) reminds us, the process of social secularization - which separated the church from the state and its institutions - had to be taught and learned, an activity invariably relegated to schools, then antiracism can follow a similar path and achieve an analogous solution. Thus we recommend antiracist intervention in scholastic curricula and teaching practices.

Based on the cases that we've briefly reviewed here, it's possible that significant change can result from proactive teachers working against racism in schools, despite the preponderance of study books shot through with racism. Although the task shouldn't fall squarely on teachers' shoulders, it's impossible to take on the job of cleaning up educational curricula with the goal of eliminating racism from schools without giving due weight to the role of the teacher. In this respect, J. C. Callirgos (1993), expert on the topic of racism in Peruvian education, argues that it would be possible to have curricula that promote an ideal scholastic culture free of racism but this wouldn't be a guaranteed solution, since a school could fall easy prey to the truly existent school culture, full 
of racism, that tends to impose itself over any obstacle. Thus our proposal is based on two concurrent measures: 1) Revising and cleaning up textbooks and curricula such that they are cleared of all hints of racism, and 2) Investing in teacher training towards the same end.

In the meantime, the most convenient thing is to trust the competence of educators. They can counteract racism, as to date they are the ones who execute the educational act. They are, much to the contrary of official vilification, the most genuine source of hope for real change in this matter.

\section{Bibliography}

Aguilar Nery, J. (2012). "Diferencia racial en docentes de educación básica de Tijuana y Tecate. Un estudio exploratorio". En: Culturales, vol. 8, núm. 15, Universidad Autónoma de Baja California, pp. 47-80.

Balibar, E. e I. Wallerstein. (1990). Race, nation, classe. Les identités ambigües. París: La Découverte.

Baronnet, B. (2013). "Racismo y discriminaciones en el sistema educativo mexicano". En: Ascencio, Gabriel (coord.). Teoría y práctica de la educación intercultural en Chiapas. México: PROIMMSE-IIA-UNAM, pp. 63-79.

Basave, A. (1992). México mestizo: análisis del nacionalismo mexicano en torno a la mestizofilia. México: Fondo de la Cultura Económica.

Bertely, M. (2011). "Aproximación a la discriminación con énfasis en el tratamiento ciudadano". En: López, N. (coord.). Escuela, identidad y discriminación. Buenos Aires: IIPE-UNESCO, pp. 27-65.

Bourdieu, P. (1990). Sociología y cultura. México: Grijalbo.

Callirgos, J. C. (1993). "La discriminación en la socialización escolar". En: Separata. Lima: Fondo Editorial de la Pontificia Universidad Católica del Perú. Disponible en: http://www.cholonautas.edu.pe/modulo/upload/Callirgos.pdf

Carlos Fregoso, G. (2016). "Racismo y educación superior: estudiantes indígenas en dos centros universitarios de la Universidad de Guadalajara, Jalisco, en un marco de políticas interculturales". Tesis de Doctorado en Investigación Educativa, Xalapa: Universidad Veracruzana.

Castellanos Guerrero, A. (2012). "La construcción del Otro en ciudades mexicanas. Del pensamiento liberal y la exclusión neoliberal”. En: Castellanos, Alicia y Gisela Landázuri (coords.). Racismo y otras formas de intolerancia de Norte a Sur en América Latina. México: UAM-I/ Juan Pablos Editor, pp. 99-124.

Castellanos Guerrero, A. (coord.) (2003). Imágenes del racismo en México. México: Plaza y Valdés.

Cejas, M. I. (coord.) (2004). Leer y pensar el racismo, Guadalajara. México: UdeG/UAM-X/Municipio de Zapopan. 
Croizet, J. C. (2012). "On the Fatal Attractiveness of Psychology: Racism of Intelligence in Education". En: Smeyers, P. y M. Depaepe (eds.). Educational Research: The Attraction 33 of Psychology, Educational Research 6, Springer, pp. 33-51.

Díaz-Couder, E., E. Gigante y G. Ornelas (coords.) (2015). Diversidad, ciudadanía y educación. Sujetos y contextos. México: Universidad Pedagógica Nacional.

Dubet, F. y Martuccelli, D. (1998). En la escuela. Sociología de la experiencia escolar. Madrid: Losada.

Esteva, G. (2011). “Más allá de la educación”. En: Meyer, L. y B. Maldonado (coords.). Comunalidad, educación y resistencia indígena en la era global. Oaxaca: CSEIIO, pp. 159-174.

Gall, O. (2004). "Identidad, exclusión y racismo: reflexiones teóricas y sobre México". En: Revista Mexicana de Sociología 66(2). México: Instituto de Investigaciones Sociales-UNAM, pp. 221259.

(2007). "Racismo y modernidad: preguntas y planteamientos". En: Gall, O. (coord.). Racismo, mestizaje y modernidad: visiones desde latitudes diversas. México: UNAM, pp. 63-88.

Gallo, S. (Org.) (2014). As diferentes faces do racismo e suas implicações na scola. Campinas: Leitura Crítica/alb.

Gnade, J. R. (2008). "Raza, racismo y educación escolar en México". Tesis de doctorado en Estudios Latinoamericanos. México: FFyL-UNAM.

Gómez Izquierdo, J. (2005). Los caminos del racismo en México. México: Plaza y Valdés/BUAP.

Gómez Izquierdo, J. (2008). El camaleón ideológico. Nacionalismo, cultura y política en México durante los años del presidente Lázaro Cárdenas (1934-1940). México: Benemérita Universidad Autónoma de Puebla/Instituto de Ciencias Sociales y Humanidades.

Habermas, J. (1999). La inclusión del otro. Barcelona: Paidós.

Hamel, E. et al. (2004). “'Qué hacemos con la castilla' La enseñanza del español como segunda lengua en un currículo intercultural bilingüe de educación indígena”. En: Revista Mexicana de Investigación Educativa. Sección temática: Educación intercultural, IX, (20), México: Universidad Autónoma Metropolitana/Consejo Mexicano de Investigación Educativa, pp. 83107.

Hernández Rosete, D. (en prensa). Creencias sobre ausentismo y rezago escolar de niños indígenas bilingües en escuelas de La Merced. México.

Iturriaga, E. (2011). "Las élites de la ciudad Blanca: racismo, prácticas y discriminación étnica en Mérida, Yucatán". Tesis de doctorado en el Instituto de Investigaciones Antropológicas. México: FFyL-UNAM.

Jordá Hernández, J. (2000). Proceso de formación docente y propuesta pedagógica en las Lep y lepmi'90. México: Universidad Pedagógica Nacional.

Klein, M. G. et al. (2014). "Desde Chiapas: Criterios básicos para la exigencia de pertinencia cultural y lingüística en la educación". En: Incidencia Civil en Educación A.C. Desenmascarar la 
discriminación. La violencia del sistema educativo mexicano hacia los pueblos originarios y las personas con discapacidad. México: ICE A.C., pp. 69-117.

Maldonado Alvarado, B. (2000). Los indios en las aulas. Dinámicas de dominación y resistencia en Oaxaca. Oaxaca: Centro INAH.

Masferrer, C. (2012). En: Gómez Quintero, Natalia, "Ven discriminación en libros de la SEP". El Universal. México, domingo 26 de febrero de 2012, sección 'Nación”. Recuperado en: http:// www.eluniversal.com.mx/nacion/194275.html (consultado 17 de abril de 2016).

McCarthy, C. (1993). Racismo y curriculum. La desigualdad social y las teorías y políticas de las diferencias en la investigación contemporánea sobre la enseñanza. Madrid: Morata.

Mejía, C. y S. Sarmiento (1987). Lucha indígena. Un reto a la ortodoxia. México: Instituto de Investigaciones Sociales-UNAM / Siglo XXI.

Mena, M. I. (2011). "Indagando el racismo, interpelando al docente: estudio de caso sobre manifestaciones de racismo y discriminación racial en las escuelas públicas de Bogotá”. En: López, N. (coord.). Escuela, identidad y discriminación. Buenos Aires: IIPE-UNESCO, pp. 149-164.

Menéndez, E. L. (enero-junio 2001). "Biologización y racismo en la vida cotidiana". En: Alteridades, 11(21). México: UAM-I, pp. 5-39.

(2016). "Los racismos son eternos". En: Conferencia Guillermo Bonfil Batalla. México: Programa PUIC, UNAM, 10 de marzo de 2016.

Molina Ludy, V. (2000). "La ideología subyacente en la discriminación hacia los pueblos indios". En: Barceló, R., M. A. Portal y M. Sánchez (coords.). Diversidad étnica y conflicto en América Latina. El indio como metáfora en la identidad nacional. Vol. II. México: UNAM / Plaza y Valdés, pp. 147-174.

Moreno Figueroa, M. (2010). "Distributed Intensities: Whiteness, Mestizaje and the Logics of Mexican Racism". Ethnicities 10, pp. 387-401.

Muñoz Cruz, H. (1987). Funciones sociales y conciencia del lenguaje. Xalapa: Universidad Veracruzana.

Muñoz Sánchez, P. (2015). "Movimientos sociales surgidos por una Educación Indígena Intercultural: casos en Guatemala y México”. En: Gehrig, R. y P. Muñoz Sánchez (coords.). Educación, identidad y derechos como estrategias desarrollo de los pueblos indígenas. Murcia: UCAM, pp. 114-132.

Navarrete, F. (2016). "Alfabeto racista mexicano I". En: Horizontal, 3 de marzo de 2016. Entrada A de Aspiracional, disponible en: http://horizontal.mx/alfabeto-racista-mexicano-1/

París Pombo, M. D. (2002). "Estudios sobre el racismo en América Latina". En: Política y Cultura (17). México: Universidad Autónoma Metropolitana, Unidad Xochimilco, pp. 289-310.

Pérez Ruiz, M. L. y A. Argueta Villamar (2015). "Jóvenes indígenas como promotores culturales. Dos experiencias mexicanas (1951-1992)”. En: Pérez Ruiz, M. L., V. Ruiz Lagier y S. Velasco 
Cruz (coords.) Interculturalidad(es). Jóvenes indígenas: educación y migración. México: Universidad Pedagógica Nacional, pp. 27-75.

Quijano, A. (2000). "Colonialidad del poder, eurocentrismo y América Latina". En: Lander, Edgardo (comp.). La colonialidad del saber: eurocentrismo y ciencias sociales. Perspectivas latinoamericanas. Buenos Aires: CLACSO/UNESCO.

Ramírez, E. (2006). Educación indígena en México. México: UNAM.

Rebolledo, Nicanor (2010). "Indigenismo, bilingüismo y educación bilingüe en México: 19392009”. En: Velasco Cruz, S. y A. Jablonska (coords.) Construcción de políticas educativas interculturales en México: Debates, tendencias, problemas, desafios. México: Universidad Pedagógica Nacional, pp. 113-157.

Saldívar, E. (2012). "Racismo en México: apuntes críticos sobre etnicidad y diferencias culturales". En: Castellanos, A. y G. Landázuri (coords.) Racismo y otras formas de intolerancia de Norte a Sur en América Latina. México: UAM-I/Juan Pablos Editor, pp. 49-98.

Urías Horcasitas, B. (2007). Historias secretas del racismo en México (1920-1950). México: Tusquets.

Van Dijk, T. (2007). Racismo y discurso en América Latina. Barcelona: Gedisa.

Velasco Cruz, S. (2015). "La escolaridad de los docentes indígenas de México". Revista Interamericana de Educación de Adultos 37(2), CREFAL, pp. 85-102.

Velasco Cruz, S. (2016). "Racismo y educación en México". Revista Mexicana de Ciencias Políticas y Sociales. UNAM, (61)226, México: UNAM, pp. 309-338.

Wieviorka, M. (2009). Racismo, una introducción, Madrid: Gedisa. 